\title{
The Role of Endothelin-1 and Endothelin Receptor Antagonists in Inflammatory Response and Sepsis
}

\author{
Agata Kowalczyk $\cdot$ Paulina Kleniewska • \\ Michal Kolodziejczyk • Beata Skibska • \\ Anna Goraca
}

Received: 13 November 2013/ Accepted: 18 July 2014/Published online: 7 October 2014

(C) The Author(s) 2014. This article is published with open access at Springerlink.com

\begin{abstract}
Endothelin-1 (ET-1) is a potent endogenous vasoconstrictor, mainly secreted by endothelial cells. It acts through two types of receptors: ETA and ETB. Apart from a vasoconstrictive action, ET-1 causes fibrosis of the vascular cells and stimulates production of reactive oxygen species. It is claimed that ET-1 induces proinflammatory mechanisms, increasing superoxide anion production and cytokine secretion. A recent study has shown that ET-1 is involved in the activation of transcription factors such as $\mathrm{NF}-\kappa \mathrm{B}$ and expression of proinflammatory cytokines including TNF- $\alpha$, IL-1, and IL-6. It has been also indicated that during endotoxaemia, the plasma level of ET-1 is increased in various animal species. Some authors indicate a clear correlation between endothelin plasma level and morbidity/mortality rate in septic patients. These pathological effects of ET-1 may be abrogated at least partly by endothelin receptor blockade. ET-1 receptor antagonists may be useful for prevention of various vascular diseases. This review summarises the current knowledge regarding endothelin receptor antagonists and the role of ET-1 in sepsis and inflammation.
\end{abstract}

Keywords Endothelins · Sepsis - Inflammation · Reactive oxygen species · Endothelin receptor antagonists

\footnotetext{
A. Kowalczyk $(\bowtie) \cdot$ P. Kleniewska · A. Goraca

Chair of Experimental and Clinical Physiology, Department of Cardiovascular Physiology, Medical University of Lodz,

Mazowiecka 6/8, 92-215 Lodz, Poland

e-mail: akkowalczyk@o2.pl

M. Kolodziejczyk · B. Skibska

Chair of Applied Pharmacy, Faculty of Pharmacy, Medical

University of Lodz, Lodz, Poland
}

\section{Pathogenesis of Sepsis}

Sepsis is defined as a systemic inflammatory response syndrome, most commonly provoked by severe bacterial infection (Naito et al. 2014; Sagy et al. 2013; Zhang et al. 2014) This critical condition, with a mortality rate of about $50-80 \%$, is characterised by hyperthermia or hypothermia, tachypnea, tachycardia, leucocytosis or leucopenia, with immature neutrophils, and organ dysfunction due to impaired tissue perfusion (Sagy et al. 2013). Endotoxic shock is also associated with pulmonary hypertension, systemic hypotension and cardiac dysfunction (Forni et al. 2005). The mechanisms underlying the pathogenic effects of sepsis are still not completely understood.

The primary cause of escalated inflammatory response in septic shock is the presence of bacterial toxins. These include the lipopolysaccharide (LPS) endotoxin, which is a compound of a Gram-negative bacterial cell wall and an exotoxin (superantigen) from Gram-positive bacteria. When released into the blood, these bacterial products induce macrophages to secrete large amounts of inflammatory cytokines like tumour necrosis factor (TNF)- $\alpha$, interleukin (IL)-1, IL-6, and IL-8, by the activation of signalling cascades such as nuclear factor (NF)- $\mathrm{kB}$ and mitogen-activated protein kinase (MAPKs) pathways. Exotoxins also activate T-lymphocytes to produce proinflammatory mediators, IL-2 and interferon $\gamma$, which stimulate inducible nitric oxide synthase (iNOS) to produce nitric oxide (NO). Together with IL-2, they also intensify the release of IL- 1 and TNF- $\alpha$ from macrophages (Roth and De Souza 2001; Sagy et al. 2013; Zhang et al. 2014). Furthermore, septic shock is also associated with an increased level of platelet-activating factor, thromboxane A2, leukotrienes, macrophage inflammatory protein-1, prostaglandin E2 (PGE2), cyclooxygenase (COX)-2 
mRNA and endothelin-1 (ET-1) (Dilshara et al. 2014; Jesmin et al. 2014; Keller et al. 2006; Roth and De Souza 2001). Under pathological conditions, endotoxin stimulates endothelin systems to release large amounts of endothelin into the blood stream. Likewise, the levels of ETA and ETB receptor mRNA are also elevated in some tissues (Forni et al. 2005). LPS-induced sepsis impairs the integrity of the endothelial barrier resulting in endothelial cell injury, which contributes to greater permeability of endothelial cells and impaired homeostasis, and induces the release of cytokines and reactive oxygen species (ROS). Plasma levels of ET-1 are elevated in septic patients and are associated with the severity of the illness. Some authors indicate a clear correlation between endothelin plasma level and morbidity and mortality in septic patients (Pan et al. 2012).

\section{The Endothelin System}

The endothelins are a family of 21 amino acid peptides with three distinct isoforms: ET-1, ET-2 and ET-3. ET-1 is the most abundant and the best described isoform. ET-2 and ET-3 were identified later and are not as well-studied (Motte et al. 2006; Yanagisawa et al. 1988). ET-1 is produced in a variety of cells (Table 1) and there are many factors which regulate its secretion (Table 2). Physical and chemical stimulants activate ET-1 gene expression in endothelial cells by the DNA binding of transcription factors such as activator protein-1, GATA-2, smad, hypoxia inducible factor- 1 and NF- $\kappa \mathrm{B}$ (Rodriguez-Pascual et al. 2003; Wanecek et al. 2000; Wort et al. 2009).

Two types of endothelin receptors are found in mammals, ETA and ETB receptors, which belong to the G protein-coupled receptors family. ETA receptors are located mostly in vascular smooth muscle cells (VSMC), where they are responsible for potent vascular contraction (Fig. 1), cell proliferation and a proinflammatory effect. ETB receptors include two subtypes: $\mathrm{ETB}_{1}$, which is expressed on endothelial cells and evokes NO-mediated vasodilation, and $\mathrm{ETB}_{2}$, also present in VSMC, which causes contraction (Hynynen and Khalil 2006; Yanagisawa et al. 1988). Stimulation of $\mathrm{ETB}_{1}$ receptors also results in the release of other vasodilatory factors such as prostacyclin $\left(\mathrm{PGI}_{2}\right)$ and endothelium-derived hyperpolarizing factor. Furthermore, it is suggested that endothelial ETB receptors take part in ET-1 clearance, but findings are not unequivocal (Hynynen and Khalil 2006; Kawanabe and Nauli 2011; Ohkita et al. 2012).

So far, ETA and ETB receptors have been detected in many cell types other than blood vessels (Table 1), but predominantly in cardiovascular tissues (Hynynen and Khalil 2006). Endothelins, through their receptors, exert an

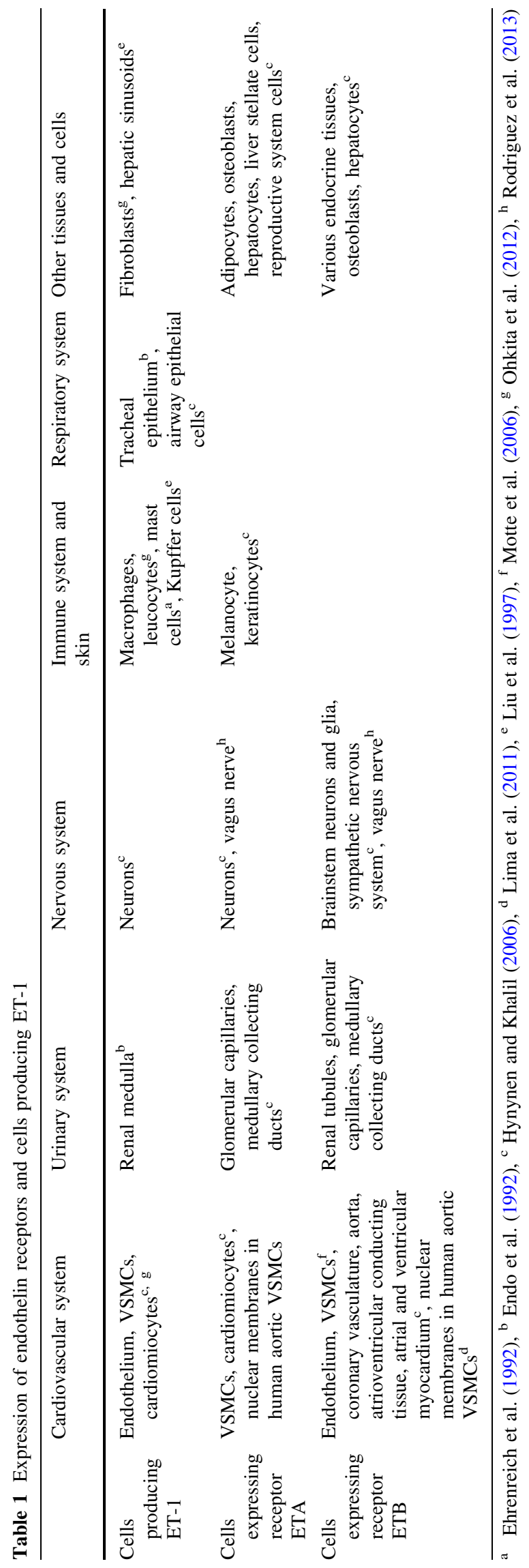


Table 2 Factors, which stimulate and inhibit release of ET-1

\begin{tabular}{|c|c|}
\hline Factors stimulating release of ET- 1 & $\begin{array}{l}\text { Factors inhibiting } \\
\text { release of ET-1 }\end{array}$ \\
\hline Low shear stress ${ }^{j}$ & High shear stress ${ }^{\mathrm{f}}$ \\
\hline Adrenalin ${ }^{\mathrm{i}}$ & Nitric oxide \\
\hline Thrombin $^{\mathrm{e}}$ & Prostacyclin ${ }^{c}$ \\
\hline Angiotensin $\mathrm{II}^{5}$ & Heparin $^{\mathrm{e}}$ \\
\hline Hypoxia $^{\mathrm{e}}$ & Prostaglandin ${ }^{\mathrm{e}}$ \\
\hline Vasopressin ${ }^{\mathrm{c}}$ & Atrial natriuretic peptide ${ }^{\mathrm{C}}$ \\
\hline \multicolumn{2}{|l|}{ Endotoxin (LPS) ${ }^{\mathrm{g}}$} \\
\hline \multicolumn{2}{|l|}{ IL- ${ }^{d}$} \\
\hline \multicolumn{2}{|l|}{ Transforming growth factor- $\beta^{c}$} \\
\hline \multicolumn{2}{|l|}{ TNF- $\alpha^{c}$} \\
\hline \multicolumn{2}{|l|}{ Insulin $^{\mathrm{e}}$} \\
\hline \multicolumn{2}{|l|}{ Free radicals ${ }^{\mathrm{e}}$} \\
\hline \multicolumn{2}{|l|}{ Cardiotrophin- $1^{\mathrm{e}}$} \\
\hline \multicolumn{2}{|l|}{ Homocysteine $^{\mathrm{a}}$} \\
\hline \multicolumn{2}{|l|}{ IL-6 ${ }^{\mathrm{h}}$} \\
\hline Calcium ions ${ }^{\mathrm{b}}$ & \\
\hline
\end{tabular}

a Duan et al. (2008), ${ }^{\mathrm{b}}$ Hukovic and Hadziselimovic (1998), ${ }^{\mathrm{c}} \mathrm{Hy}-$ nynen and Khalil (2006), ${ }^{\mathrm{d}}$ Maemura et al. (1992), ${ }^{\mathrm{e}}$ Motte et al. (2006), ${ }^{\mathrm{f}}$ Shao et al. (2011), ${ }^{\mathrm{g}}$ Sugiura et al. (1989), ${ }^{\mathrm{h}}$ Yamashita et al. (1993), ${ }^{\mathrm{i}}$ Yanagisawa et al. (1988), ${ }^{\mathrm{j}}$ Yoshizumi et al. (1989)

influence on the function of many organs like the heart, the kidneys, the lungs and the liver (Lima et al. 2011; Rodriguez et al. 2013). Apart from participating in the regulation of vascular tone, endothelins take part in vascular, myocardial and bone remodelling, inhibition of apoptosis and salt-water retention. Furthermore, endothelins can contribute to bronchoconstriction, angiogenesis and neuropathic pain (Rodriguez et al. 2013; Thakkar et al. 2006).

\section{ET-1 and ROS}

It is known that ET-1 stimulates the production of ROS, primarily superoxide anions $\left(\mathrm{O}_{2}{ }^{-}\right)$, and consequently leads to the development of oxidative stress. When given intravenously, the peptide initially causes vasodilation of blood vessels followed by their subsequent long lasting contraction, resulting in ischemia of internal organs and the dysfunction of the endothelium. These changes can lead to abundant ROS generation (Dong et al. 2005; Loomis et al. 2005; López-Sepúlveda et al. 2011; Thakali et al. 2005). Some studies have shown the oxidative stress caused by ET-1 to be associated with augmentation of lipid peroxidation and reduction of intracellular GSH (glutathione) and SH groups (Scalera et al. 2002; Viswanatha Swamy et al. 2011). According to the literature, both the ETA (Elmarakby et al. 2005) and ETB receptors (Dong et al. 2005) mediate ROS generation. Callera et al. (2003) demonstrated that elevated concentrations of ET-1 induce the synthesis of $\mathrm{O}_{2}{ }^{-}$through ETA receptors. Xu et al. (2003) report a significant reduction in lipid peroxidation products content in the ischemic myocardium after applying BQ123, a blocker of the ETA receptor. Other authors note a

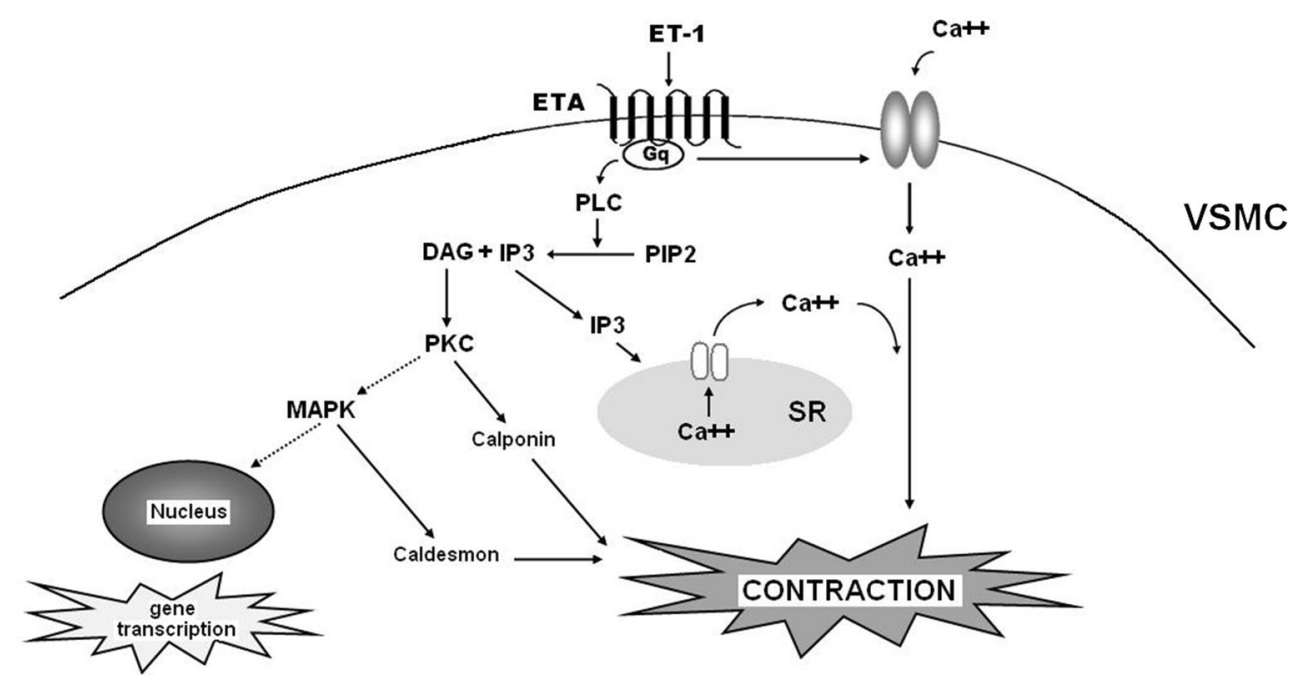

Fig. 1 ETA receptor-mediated VSMC signalling pathways. Activation of the ETA receptor stimulates phospholipase C (PLC) to generate inositol 1,4,5-trisphosphate $\left(\mathrm{IP}_{3}\right)$ and diacylglycerol (DAG) from phosphatidylinositol 4.5-bisphosphate $\left(\mathrm{PIP}_{2}\right)$. $\mathrm{IP}_{3}$ induces $\mathrm{Ca}^{2+}$ outflow from intracellular stores in sarcoplasmic reticulum (SR). Furthermore, the ETA receptor acts on nonselective plasmalemmal $\mathrm{Ca}^{2+}$ channels causing $\mathrm{Ca}^{2+}$ input from the extracellular space. Consequently, increased concentrations of $\mathrm{Ca}^{2+}$ leads to the contraction of VSMC. The activated ETA receptor also stimulates cell growth. Production of DAG activates protein kinase C (PKC), which is responsible for the mitogenic function of endothelin, and which also induces a $\mathrm{Ca}^{2+}$-independent pathway of VSMC contraction involving calponin phosphorylation. PKC affects gene transcription through activation of the Ras/Raf/MEK/MAPK cascade. MAPK phosphorylates caldesmon, which increases VSMC contraction (Hynynen and Khalil 2006; Khalil 2011; Lima et al. 2011) 
reduction of lipid peroxidation in various organs during oxidative stress when using this blocker (Briyal et al. 2011). BQ123 has been found to block increased production of $\mathrm{O}_{2}{ }^{-}$in ET-1-induced oxidative stress in the arteries and veins of patients with coronary artery disease (Cerrato et al. 2012), has been associated with a significant increase in the concentration of total glutathione and superoxide dismutase (SOD) activity after application (Briyal et al. 2011), as well as a significant increase in the activity of the antioxidant enzymes SOD and catalase in cases of ET-1induced oxidative stress (Ozdemir et al. 2006).

Studies on blocking ETB receptors are ambiguous. Wedgwood et al. (2001) note that the ETB receptor antagonist (Res-701-3) increased the production of $\mathrm{H}_{2} \mathrm{O}_{2}$ in the smooth muscle cell culture from the pulmonary artery, but not in endothelial cells. However, other studies indicate that the ETB receptor blockade reduces the ROS production in various tissues (Dai et al. 2004). Moreover, Piechota-Polanczyk et al. (2012) report a significant increase in the concentration of GSH, but insignificant increase in the ratio of GSH/GSSG in the rat heart after application of BQ788. On the other hand, Leonard et al. (2011, 2012) did not observe any changes in the concentration of glutathione in rats after administration of BQ788.

\section{The Proinflammatory Effect of ET-1}

Several studies have demonstrated that ET-1 contributes to the development of inflammatory processes in the vascular wall. ET-1 has been found to be associated with an inflammatory response involving activation of transcription factors such as NF- $\mathrm{kB}$ and expression of proinflammatory cytokines including TNF- $\alpha$, IL-1 and IL-6 (Yeager et al. 2012). These transcription factors and proinflammatory cytokines in turn stimulate ET-1 production (Virdis and Schiffrin 2003). Bellisai et al. (2011) report that ET-1 increases the synthesis of TNF- $\alpha$ in macrophages and monocytes. This cytokine enhances the inflammatory response by stimulating the chemotaxis and phagocytosis of macrophages, monocytes and neutrophils. Increased production of ROS in different types of cells occurs via the NF- $\kappa \mathrm{B}, \mathrm{COX}$ and NADPH oxidase-dependent pathways (Donate et al. 2012; Kleniewska et al. 2013; Piechota and Goraca 2011).

Recent studies have shown that the ETA receptor antagonist BQ123 has a beneficial influence on the concentration of TNF- $\alpha$ (Ozdemir et al. 2006). Ford et al. (2008) note that the ETA receptor blockade lowered the concentration of TNF- $\alpha$ in patients after bypass grafting via the antagonist BQ123. Chen et al. (2010) confirmed that BQ123 inhibited the expression of TNF- $\alpha$ and IL- $1 \beta$ in the lungs of rats during oxidative stress induced by intraperitoneal administration of an extract from the cigarette smoke. Moreover, an ETB receptor blockade may also have an influence on TNF- $\alpha$ synthesis. In a recent study by Tonari et al. (2012), BQ788 showed significant inhibition of the expression of TNF- $\alpha$ when applied to patients with damage to the optic nerve. However, Piechota-Polanczyk et al. (2012) report no significant reduction in the concentrations of TNF- $\alpha$ in the rat heart following the application of BQ788.

Furthermore, an excess amount of proinflammatory cytokines activates prostaglandin production during inflammatory responses in a number of cell types such as vascular endothelial and smooth muscle cells. Prostaglandins are synthetized by COX, which is also known as prostaglandin endopeptidase synthase. In this process, phospholipase A2 catalyses the release of arachidonic acid (AA) from membrane phospholipids, while COX catalyzes the conversion of AA into prostaglandins. There are two COX isoforms: COX-1 is constitutively expressed under normal conditions in the most tissues. This isoform takes part in regulating normal physiological responses and controls vascular homeostasis. COX-2 is not detectable in most normal cells and tissues, but its expression increases in inflammatory cells. Thus, COX-2 may play a crucial role in the development of various inflammatory responses including vascular inflammation. Recent studies have indicated that ET-1 induces COX-2 expression and PGE2 release by MAPKs and NF- $\kappa B$ (Lin et al. 2013).

ET-1 enhances the expression of adhesion molecules on vascular endothelial cells and stimulates the aggregation of polymorphonuclear neutrophils (PMNs) contributing to inflammation and endothelial dysfunction. Li et al. (2003) postulate that ET-1 stimulates the arterial vascular adhesion molecule-1 (VCAM-1) in hypertensive patients. VCAM-1 and the intracellular adhesion molecule-1 induce firm adhesion of inflammatory cells at the vascular surface (Blankenberg et al. 2003). PMNs may contribute to myocardial damage by releasing ROS, proteases and arachidonic acid metabolites (Hansen 1995). Oktar et al. (2000) indicate that ET-1 causes an accumulation of PMNs, oxidative stress, and mucosal dysfunction in the rat small intestine. Gonon et al. (2001) showed that the ET receptor blockade attenuates the accumulation of neutrophils and myeloperoxidase activity in the ischemic myocardium. It has been shown that the vascular injury caused by carotid artery ligation results in vascular inflammation and neointima formation. This action is attenuated in vascular endothelial ET-1-knockout mice (Anggrahini et al. 2009).

Increased ROS release contributes to endothelium dysfunction. Endothelial dysfunction occurs in cardiovascular diseases such as atherosclerosis. Increased expression of ET-1 was observed both in experimental models of 
atherosclerosis as well as in human atherosclerosis (Barton et al. 2003) and its level correlated with the severity of the atherosclerotic lesion. Haug et al. (1996) identify a higher expression of ET-1 in human VSMC harvested from human atherosclerotic coronary arteries than in cells from non-atherosclerotic arteries. ET-1 was associated with regions of the atherosclerotic plaque, particularly in regions with high macrophage content (Dashwood and Tsui 2011). It was shown that overexpression of ET-1 significantly increased the atherosclerotic lesion size in apolipoprotein $\mathrm{E}$ gene deleted mice $\left(\mathrm{ApoE}^{-/-}\right)$fed a high-fat diet. In this case, increased endothelial ET-1 expression enhances an increase in expression of genes associated with lipid synthesis in the vasculature and accelerates the progression of atherosclerosis (Simeone et al. 2011).

Li et al. (2013) have reported that ET-1 plays a role in the development of atherosclerosis and abdominal aortic aneurysm by decreasing high-density lipoprotein, increasing oxidative stress and monocyte/macrophage infiltration in both the aorta and aneurysms. So, plaque formation and endothelial function can be restored in the atherosclerosis model by the administration of ETA or dual ETA/ETB receptor antagonists. Moreover, it has been noted that tissue ET-1 concentration is more important than serum ET-1 in predicting atherosclerosis in patients with chronic kidney disease (Noshad et al. 2009). Recently, a study indicated that ethanolic extract of propolis inhibits atherosclerotic lesion formation in $\mathrm{ApoE}^{-/-}$mice fed a high-fat diet, probably by regulating the inflammatory reaction and inhibiting ET-1 (Fang et al. 2013). Overexpression of ET-1, particularly in the endothelium of mice with atherosclerosis, is accompanied by a decrease in endothelial signalling pathways responsible for endothelium-dependent relaxation and an increase in the activity of sensitive voltage-dependent potassium channels (Mian et al. 2013). ROS are important physiological messengers in vascular cells and their overproduction contributes to the progression of atherosclerosis (Freund-Michel et al. 2013). ET-1 receptor antagonists may be useful for prevention of various vascular diseases (Kitada et al. 2009, 2012).

\section{ET-1 and Endothelin Receptor Antagonists in Sepsis}

Recently, studies have addressed the role of endothelins and blockers of their receptors in the development of sepsis. During endotoxaemia, plasma endothelin level is increased in various species (Kaszaki et al. 1997; Pan et al. 2012; Piechota-Polańczyk and Gorąca 2012). In experimental models, endotoxin induces the expression of preproendothelin-1 mRNA in the lung and heart (Kaddoura et al. 1996). Infusion of ET-1 in septic shock contributed to the dysfunction of several vital organs such as liver, lung, heart and kidney (Fenhammar et al. 2011; Piechota-Polanczyk et al. 2012). It has been indicated that the infusion of ET-1 in humans causes cardiovascular changes in part resembling those observed during sepsis i.e. decreased cardiac output, vasoconstriction in the pulmonary artery, impairment of renal and splanchnic circulation (Bomberg et al. 2013; Ross 2012; Schuuring et al. 2013). It has been demonstrated in animal experiments that dual ETA/ETB endothelin blockade during endotoxaemia improves cardiopulmonary function, reduces pulmonary hypertension and lung injury and attenuates intestinal and liver microcirculatory dysfunction (Kuklin et al. 2005; Sánchez-Etayo et al. 2012). Also ETA receptor blockade alone improves the function of the lungs (Mercier et al. 2010), kidney (Rullman et al. 2010), heart (Vanêcková et al. 2005) and aorta (Tirapelli et al. 2008).

Endothelin receptor antagonists (ERAs) are a new, promising class of medicines which block the ETA and ETB endothelin receptors with varying degrees of selectivity. They form a large group consisting of nearly 40 or more compounds, and part of them is currently under investigation (Hynynen and Khalil 2006; Khalil 2011; Motte et al. 2006) as potential therapeutic objects in clinical trials (see Table 3). ERAs act on various pathophysiological mechanisms (Table 4), three of which recommended for treatment of pulmonary arterial hypertension, bosentan, ambrisentan and macitentan, are already on the world pharmaceutical market (Motte et al. 2006; Patel and McKeage 2014). However, the nonselective ERAs, bosentan and tezosentan, and selective antagonists, BQ123 and BQ788, are currently receiving the most attention with regard to the effect of ERAs on the progression of sepsis.

\section{Bosentan}

In 2001, bosentan $\left(\right.$ Tracleer $^{\circledR}$ ) became the first ERA to be registered in the USA as an oral medicine for patients with pulmonary arterial hypertension of functional class III/IV (Dupuis and Hoeper 2008; Motte et al. 2006). Many studies have shown a significant improvement in functional class and exercise capacity, as well as haemodynamic, Doppler and echocardiographic parameters after treatment with bosentan. Despite having side effects such as increases in liver transaminase content, headache, peripheral oedema, dizziness, nasal congestion and nausea, bosentan therapy is generally regarded as beneficial (Montani et al. 2013; Motte et al. 2006). Bosentan also has been found to exert a positive therapeutic influence on the treatment of systemic sclerosis (scleroderma) and other disorders (Cozzi et al. 2013) (Table 3). 
Table 3 Main ERAs in clinical and preclinical trials

\begin{tabular}{|c|c|c|c|}
\hline ERA & Selectivity & Negative results in & Positive results in \\
\hline $\begin{array}{l}\text { Ambrisentan } \\
\quad\left(\text { Letairis }{ }^{\circledR}, \text { USA; }\right. \\
\text { Volibris }^{\circledR}, \text { EU) }\end{array}$ & ETA & $\begin{array}{l}\text { Idiopathic pulmonary fibrosis (phase I clinical } \\
\text { study) }\end{array}$ & $\begin{array}{l}\text { Treatment of pulmonary arterial hypertension associated } \\
\text { with spironolactone (ARIES trials) })^{17} \text {, therapy of } \\
\text { pulmonary arterial hypertension in children (phase } 0 \\
\text { clinical study) }\end{array}$ \\
\hline $\begin{array}{l}\text { Atrasentan (ABT- } \\
627, \mathrm{~A}-147627)\end{array}$ & ETA & $\begin{array}{l}\text { Metastatic hormone-refractory prostate cancer } \\
\text { (phase III clinical study) } \\
\text { Castration-resistant prostate cancer and bone } \\
\text { metastases (phase III clinical study) }\end{array}$ & $\begin{array}{l}\text { Diabetic nephropathy: reduced albuminuria (phase II } \\
\text { clinical study) } 1,13 \\
\text { Cerebrovascular dysfunction in diabetes: improved } \\
\quad \text { cerebrovascular relaxation (preclinical study) } \\
\text { Early atherosclerosis: improved endothelial function and } \\
\quad \text { inhibited plaque progression (phase I clinical study) } \\
\text { (14, } 33\end{array}$ \\
\hline $\begin{array}{l}\text { Avosentan (SPP } \\
\text { 301) }\end{array}$ & ETA & $\begin{array}{l}\text { Diabetic and non-diabetic chronic kidney } \\
\text { disease (ASCEND trial) }\end{array}$ & Glaucoma (preclinical study) ${ }^{14,31}$ \\
\hline $\begin{array}{l}\text { Bosentan } \\
\quad\left(\text { Tracleer }^{\circledR}\right)\end{array}$ & ETA/ETB & $\begin{array}{l}\text { Pulmonary hypertension associated with fibrotic } \\
\text { idiopathic interstitial pneumonia (phase } 0 \\
\text { clinical study) }\end{array}$ & $\begin{array}{l}\text { Ovarian ischaemia/reperfusion (I/R) injury: limited } \\
\text { oxidative damage and I/R injury (preclinical study) }{ }^{27} \\
\text { Rheumatoid arthritis: antinociceptive and anti-inflammatory } \\
\text { activity (preclinical study) } \\
\text { Diabetes: improved learning and memory abilities } \\
\quad \text { (preclinical study) }\end{array}$ \\
\hline $\begin{array}{l}\text { Clazosentan (RO } \\
\quad 61-7790)\end{array}$ & ETA & $\begin{array}{l}\text { Prevention of occurrence of cerebral vasospasm } \\
\text { results (CONSCIOUS- } 2 \text { and halted CONSCIO }\end{array}$ & $\begin{array}{l}\text { after aneurysmal subarachnoid haemorrhage: controversial } \\
\text { US-3 trials) }{ }^{16,28}\end{array}$ \\
\hline $\begin{array}{l}\text { Darusentan (LU- } \\
\text { 135252) }\end{array}$ & ETA & Resistant hypertension: significantly decreased $\mathrm{b}$ & lood pressure, but serious adverse events (DORADO trial) ${ }^{7}$ \\
\hline $\begin{array}{l}\text { Macitentan } \\
\quad\left(\text { Opsumit }^{\circledR}\right)\end{array}$ & ETA/ETB & Idiopathic pulmonary fibrosis (MUSIC trial) ${ }^{23}$ & $\begin{array}{l}\text { Ovarian cancer: inhibited progression, reduced tumour } \\
\text { weight (preclinical study) }{ }^{10,11}\end{array}$ \\
\hline $\begin{array}{l}\text { Tezosentan (RO } \\
\text { 61-0612) }\end{array}$ & ETA/ETB & $\begin{array}{l}\text { Right ventricular failure (TACTICS trial) } \\
\text { Type } 2 \text { hepatorenal syndrome (phase } 0 \text { clinical } \\
\text { study) })^{32}\end{array}$ & $\begin{array}{l}\text { Ischemic cardiomyopathy: protective properties (preclinical } \\
\text { study) })^{25}\end{array}$ \\
\hline $\begin{array}{l}\text { Zibotentan } \\
\quad(\text { ZD4054) }\end{array}$ & ETA & $\begin{array}{l}\text { Metastatic and non-metastatic hormone- and } \\
\text { castration-resistant prostate cancer (phase III } \\
\text { clinical study) })^{18,20,26} \\
\text { Ovarian cancer (phase II clinical study) } \\
\text { Non-small cell lung cancer (phase II clinical } \\
\text { study) }^{3}\end{array}$ & Colorectal cancer (preclinical study) ${ }^{8}$ \\
\hline
\end{tabular}

1 Braun et al. (2012), ${ }^{2}$ Carducci et al. (2007), ${ }^{3}$ Chouaid et al. (2011), ${ }^{4}$ Cognetti et al. (2013), ${ }^{5}$ Corte et al. (2014), ${ }^{6}$ Denault et al. (2013), ${ }^{7}$ Grassi (2011), ${ }^{8}$ Haque et al. (2013), ${ }^{9}$ Imhof et al. (2011), ${ }^{10}$ Kim et al. (2011), ${ }^{11}$ Kim et al. (2012), ${ }^{12}$ Kohan and Pollock (2013), ${ }^{13}$ Kohan et al. (2011), ${ }^{14}$ Konieczka et al. (2011), ${ }^{15} \mathrm{Li}$ et al. (2011), ${ }^{16}$ Macdonald et al. (2013), ${ }^{17}$ Maron et al. (2013), ${ }^{18}$ Miller et al. (2013), ${ }^{19}$ Motte et al. (2006), ${ }^{20}$ Nelson et al. (2012), ${ }^{21}$ Quinn et al. (2013), ${ }^{22}$ Raghu et al. (2013a), ${ }^{23}$ Raghu et al. (2013b), ${ }^{24}$ Reriani et al. (2010), ${ }^{25}$ Ryu et al. (2009), ${ }^{26}$ Schelman et al. (2011), ${ }^{27}$ Sengul et al. 2013, ${ }^{28}$ Shen et al. (2013), ${ }^{29}$ Singh et al. (2014), ${ }^{30}$ Takatsuki et al. (2013), ${ }^{31}$ Wang et al. (2011), ${ }^{32}$ Wong et al. (2008), ${ }^{33}$ Yoon et al. (2013)

A common feature of sepsis is microcirculatory dysfunction. However, Krejci et al. (2003) note improved microcirculatory blood flow in the pancreas, gastric, skeletal muscle and colon mucosa of septic pigs treated with bosentan. Further, Iskit et al. (2004) report that bosentan at a dose of $30 \mathrm{mg} / \mathrm{kg}$ b.w. decreases caecal ligation and reduce liver, kidney and spleen injury, improving survival $(p<0.05)$ in a mouse model of polymicrobial sepsis. They also suggest that antagonism of endothelin receptors during the hypodynamic phase of septic shock gives much better results. More detailed data provided by Keller et al. (2006) confirm that the administration of LPS results in increased expressions of ET-1, iNOS, and COX-2 mRNA. They also report a significant inhibition of the up-regulation of ET-1, iNOS, and COX-2 mRNA after treatment of rats with $30 \mathrm{mg} / \mathrm{kg}$ b.w. bosentan, thus demonstrating its antiinflammatory and therapeutic properties.

\section{Tezosentan}

The first study concerning the effects of tezosentan on the cardiovascular system in sepsis was conducted by Chin et al. (2002). During endotoxaemia, endothelin antagonism with this ERA maintained renal and cardiac functions, preventing decreases in cardiac index, renal blood flow, 
Table 4 The effects of endothelin receptor blockers on various pathophysiological mechanisms in sepsis-summary

\begin{tabular}{|c|c|c|c|}
\hline Blocker & Selectivity & Effect & References \\
\hline \multirow[t]{4}{*}{ BQ123 } & \multirow[t]{4}{*}{ ETA } & $\begin{array}{l}\text { Reduction in lipid } \\
\text { peroxidation } \\
\text { products, TNF- } \alpha \\
\text { and } \mathrm{H}_{2} \mathrm{O}_{2} \\
\text { concentration }\end{array}$ & $\begin{array}{l}\text { Briyal et al. (2011), } \\
\text { Piechota et al. } \\
\text { (2011), Piechota- } \\
\text { Polańczyk and } \\
\text { Gorąca (2012), Xu } \\
\text { et al. (2003) }\end{array}$ \\
\hline & & $\begin{array}{l}\text { Increase in the } \\
\text { concentration of } \\
\text { total glutathione, } \\
\text { elevated SOD and } \\
\text { catalase activity }\end{array}$ & $\begin{array}{l}\text { Ozdemir et al. } \\
\text { (2006) }\end{array}$ \\
\hline & & $\begin{array}{l}\text { Decrease in the } \\
\text { concentration of } \\
\text { TNF- } \alpha \text { and } \\
\text { inhibition of TNF- } \\
\alpha \text { expression }\end{array}$ & $\begin{array}{l}\text { Chen et al. (2010), } \\
\text { Ford et al. (2008), } \\
\text { Ozdemir et al. } \\
\text { (2006) }\end{array}$ \\
\hline & & $\begin{array}{l}\text { Inhibition of IL-1 } \beta \\
\text { expression }\end{array}$ & Chen et al. (2010) \\
\hline \multirow[t]{2}{*}{ Bosentan } & \multirow[t]{2}{*}{ ETA/ETB } & $\begin{array}{l}\text { Decrease in organ } \\
\text { injury, improved } \\
\text { microcirculatory } \\
\text { blood flow in } \\
\text { splanchnic organs } \\
\text { and in peripheral } \\
\text { tissues }\end{array}$ & $\begin{array}{l}\text { Iskit et al. (2004), } \\
\text { Krejci et al. } \\
(2003)\end{array}$ \\
\hline & & $\begin{array}{l}\text { Inhibition of the up- } \\
\text { regulation of ET- } \\
1, \text { iNOS, and } \\
\text { COX-2 mRNA }\end{array}$ & Keller et al. (2006) \\
\hline Tezosentan & ETA/ETB & $\begin{array}{l}\text { Improved } \\
\text { cardiopulmonary } \\
\text { function, reduced } \\
\text { pulmonary } \\
\text { hypertension, } \\
\text { reduced lung, } \\
\text { liver, kidney and } \\
\text { spleen injury and } \\
\text { attenuated } \\
\text { intestinal, renal } \\
\text { and liver } \\
\text { microcirculatory } \\
\text { dysfunction }\end{array}$ & $\begin{array}{l}\text { Chin et al. (2002), } \\
\text { Kuklin et al. } \\
(2005)\end{array}$ \\
\hline \multirow[t]{3}{*}{ BQ788 } & \multirow[t]{3}{*}{ ETB } & $\begin{array}{l}\text { Reduction in the } \\
\text { ROS production in } \\
\text { various tissues }\end{array}$ & Dai et al. (2004) \\
\hline & & $\begin{array}{l}\text { Increase of mean } \\
\text { arterial pressure }\end{array}$ & Nitescu et al. (2008) \\
\hline & & $\begin{array}{l}\text { Protective and anti- } \\
\text { inflammatory } \\
\text { effects in the brain } \\
\text { tissue }\end{array}$ & Naito et al. (2014) \\
\hline
\end{tabular}

glomerular filtration rate and increased systemic vascular resistance in neonatal piglets (Chin et al. 2002). Further research demonstrated that tezosentan $(10 \mathrm{mg} / \mathrm{kg}$ b.w $)$ prevents mesenteric ischemia in septic mice. It significantly $(p=0.0046)$ attenuated decreases in mesenteric blood flow and limited injury to organs such as the liver, kidney and spleen. However, in this study, despite what was expected, tezosentan did not reduce ROS generation (Erdem et al. 2007). Other sepsis studies on pigs have brought similar effects, confirming that application of tezosentan results in improved intestinal and renal microcirculation, contributes to increased portal vein flow and decreased pulmonary capillary wedge pressure, and preserves cardiac index. Moreover, $\mathrm{pH}$ and arterial lactate values were better compared to the control (Andersson et al. 2008; Fenhammar et al. 2008). It is also significant that this dual blocker had no influence on TNF- $\alpha$, IL- 6 or IL-10 plasma levels, nor angiotensin II or aldosterone plasma concentration, in this model of sepsis (Fenhammar et al. 2008). A recent investigation using tezosentan and the selective ETA antagonist, TBC3711 revealed no improvement in the liver and ileum microvascular blood flow during selective antagonism, but it showed marked amelioration after tezosentan. These findings highlight the special role of the ETB receptor in mediating the microcirculatory failure in this area (Andersson et al. 2010).

\section{BQ123 and BQ788}

Selective endothelin receptor blockers like BQ123 and BQ788 have also been used in sepsis studies: the former being an ETA receptor antagonist and the latter an ETB receptor blocker. Hirata and Ishimaru (2002) report that BQ123 does not increase survival in a rat septic shock model, due to lack of improvement in LPS-induced profound hypotension. However, a dual blockade of endothelin receptors helped maintain normal mean arterial pressure. The authors also suggest that this effect does not depend on iNOS-derived NO (Hirata and Ishimaru, 2002). Similarly, Nitescu et al. (2008) note that while BQ123 did not prevent endotoxin-induced hypotension, BQ788 did, by increasing mean arterial pressure in septic rats. Moreover, marked decrease $(p<0.05)$ of renal blood flow was observed in the group treated with both BQ788 and LPS, which may indicate that the ETB receptor is responsible for renal vasodilation and maintenance of normal renal blood flow (Nitescu et al. 2008).

Some authors suggest that oxidative stress in sepsis is mediated by ET-1 and ETA receptors. Studies on a rat model have shown that LPS markedly elevates lipid peroxidation products, TNF- $\alpha$ and $\mathrm{H}_{2} \mathrm{O}_{2}$ concentration in the lung, and BQ123 administration resulted in a distinct decrease of these parameters $(p<0.05)$, except for lipid peroxidation products level, which remained elevated. This ETA blocker also reduced TNF- $\alpha$ level in lung and plasma. Furthermore, a lower dose of BQ123 $(0.5 \mathrm{mg} / \mathrm{kg})$ was 
found to be more effective than higher dose of $1 \mathrm{mg} / \mathrm{kg}$, and also prevented lung oedema development $(p<0.01)$ (Piechota et al. 2011; Piechota-Polańczyk and Gorąca 2012). On the other hand, the same study based on heart tissue demonstrated a significant reduction in lipid peroxidation products and TNF- $\alpha$, but not in $\mathrm{H}_{2} \mathrm{O}_{2}$ concentration, after BQ123 administration in experimental sepsis (Piechota-Polanczyk et al. 2012). These performance differences are probably associated with different antioxidant enzymes activities in the lung and heart.

Moreover, ETB receptor antagonism with BQ788 also reduced amplified amount of ROS, lowering lipid peroxidation products and $\mathrm{H}_{2} \mathrm{O}_{2}$ concentration. However, BQ788 did not influence increased concentration of TNF- $\alpha$ and neither BQ123 nor BQ788 affected LPS-induced activation of NF- $\kappa B$ pathway. However, Naito et al. (2014) note the

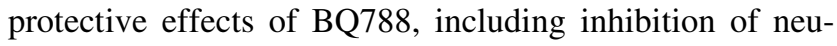
roblast apoptosis, c-FOS expression, number of reactive microglia and distinctly diminished TNF- $\alpha$ level in mouse brain tissue during sepsis. These findings may suggest that in the heart, the ETA receptor is more involved in secretion of TNF- $\alpha$ than ETB. Furthermore, presumably both endothelin receptors in heart tissue stimulate ROS generation by some other signalling pathways than NF- $\kappa B$. Nevertheless, the blockage of ETA receptor reduces ROS production and improves tissue antioxidant properties (Piechota-Polanczyk et al. 2012). These findings also confirm to some extent that ET-1 is strongly involved in the pathogenesis of septic shock, but the close links between factors inducing sepsis and increased production of ET-1 are still unclear.

\section{Towards the End}

A very recent study has revealed that the oedema-promoting effects of ET-1 might be related to augmented level of heparin-binding protein (HBP) accompanying sepsis. HBP, also termed CAP37 or azurocidin is a protein released from neutrophils, which induces vascular hyperpermeability and contributes to oedema formation during endotoxaemia. Until now, it was believed that ET-1 induces vascular leakage, but the mechanisms of this action were not established. Using a porcine sepsis model, Persson et al. (2014) report a significant decrease of HBP plasma level, as well as reduced pulmonary oedema, in animals treated with tezosentan compared to those who received ET-1 or the ETB receptor agonist sarafotoxin $6 \mathrm{c}$, both of which caused a dose-dependent increase in HBP levels similar to those observed in sepsis. These findings suggest that stimulation of both endothelin receptors activates reactions which lead to augmented secretion of HBP and this process may be abolished by nonselective ERA (Persson et al. 2014).
More than 20 years ago, ET-1 was identified as the first endothelium-derived contracting factor. Shortly after, two receptor subtypes, ETA and ETB, were discovered, which permitted the development of orally active ET-1 receptor antagonists. One of the first was the nonselective ETA/ ETB-receptor antagonist, bosentan $\left(\right.$ Tracleer $\left.^{B}\right)$, available to patients in 2001. Since then, although many ERAs have been described, not all of them are in clinical use. A novel ERA, macitentan $\left(\right.$ Opsumit $\left.{ }^{\circledR}\right)$, is a very potent nonslective blocker, with high lipophilicity (Montani et al. 2013) "sustained receptor binding and enhanced tissue penetration properties" (Sidharta et al. 2013). It is the newest and safest registered ERA (Patel and McKeage 2014), but its specific properties have not yet been studied in condition of sepsis. Similarly, a potent ETA receptor antagonist, ambrisentan (Letairis ${ }^{\circledR}$, Volibris $^{\circledR}$ ) may present favourable effects in sepsis (Montani et al. 2013; Elshaboury and Anderson 2013).

New applications for this group of medicines still remain an interesting subject of study. Antibiotics, fluids and vasopressors are most commonly used in the treatment of sepsis. Recent anti-inflammatory strategies such as highdose corticosteroids, anti-TNF- $\alpha$, IL-1-based therapies or activated protein $\mathrm{C}$, have proved to be disappointing (Xie et al. 2014). Effective clinical applications of endothelin receptor antagonists need a more thorough understanding of the physiology and pathophysiology of the ET-1 system. Endothelins, HBP and other, yet unidentified, factors involved in the bacterial toxin activation of the endothelin system might represent the main target for sepsis therapy in the future.

Acknowledgments This work was supported by Medical University of Lodz Grant No. 503/0-079-03/503-01 and Grant No. 502-03/0-07903/502-04-017.

Conflict of interest The authors declare that they have no conflict of interest.

Open Access This article is distributed under the terms of the Creative Commons Attribution License which permits any use, distribution, and reproduction in any medium, provided the original author(s) and the source are credited.

\section{References}

Andersson A, Fenhammar J, Frithiof R et al (2008) Mixed endothelin receptor antagonism with tezosentan improves intestinal microcirculation in endotoxemic shock. J Surg Res 149:138-147

Andersson A, Fenhammar J, Weitzberg E et al (2010) Endothelinmediated gut microcirculatory dysfunction during porcine endotoxaemia. Br J Anaesth 105:640-647

Anggrahini DW, Emoto N, Nakayama K et al (2009) Vascular endothelial cell-derived endothelin-1 mediates vascular inflammation and neointima formation following blood flow cessation. Cardiovasc Res 82:143-151 
Barton M, Traupe T, Haudenschild CC (2003) Endothelin, hypercholesterolemia and atherosclerosis. Coron Artery Dis 14:477-490

Bellisai F, Morozzi G, Scaccia F et al (2011) Evaluation of the effect of bosentan treatment on proinflammatory cytokine serum levels in patients affected by systemic sclerosis. Int J Immunopathol Pharmacol 24:261-264

Blankenberg S, Barbaux S, Tiret L (2003) Adhesion molecules and atherosclerosis. Atherosclerosis 170:191-203

Bomberg H, Bierbach B, Flache S et al (2013) Endothelin and vasopressin influence splanchnic blood flow distribution during and after cardiopulmonary bypass. J Thorac Cardiovasc Surg 145:539-547

Braun L, Sood V, Hogue S et al (2012) High burden and unmet patient needs in chronic kidney disease. Int J Nephrol Renovasc Dis 5:151-163

Briyal S, Philip T, Gulati A (2011) Endothelin-A receptor antagonists prevent amyloid- $\beta$-induced increase in ETA receptor expression, oxidative stress, and cognitive impairment. J Alzheimers Dis 23:491-503

Callera GE, Touyz RM, Teixeira SA et al (2003) ETA receptor blockade decreases vascular superoxide generation in DOCAsalt hypertension. Hypertension 42:811-817

Carducci MA, Saad F, Abrahamsson PA et al (2007) A phase 3 randomized controlled trial of the efficacy and safety of atrasentan in men with metastatic hormone-refractory prostate cancer. Cancer 110:1959-1966

Cerrato R, Cunnington C, Crabtree MJ et al (2012) Endothelin-1 increases superoxide production in human coronary artery bypass grafts. Life Sci 91:723-728

Chen Y, Hanaoka M, Droma Y et al (2010) Endothelin-1 receptor antagonists prevent the development of pulmonary emphysema in rats. Eur Respir J 35:904-912

Chin A, Radhakrishnan J, Fornell L et al (2002) Effects of tezosentan, a dual endothelin receptor antagonist, on the cardiovascular and renal systems of neonatal piglets during endotoxic shock. J Pediatr Surg 37:482-487

Chouaid C, Nathan F, Pemberton K et al (2011) A phase II, randomized, multicenter study to assess the efficacy, safety, and tolerability of zibotentan (ZD4054) in combination with pemetrexed in patients with advanced non-small cell lung cancer. Cancer Chemother Pharmacol 67:1203-1208

Cognetti F, Bagnato A, Colombo N et al (2013) A Phase II, randomized, double-blind study of zibotentan (ZD4054) in combination with carboplatin/paclitaxel versus placebo in combination with carboplatin/paclitaxel in patients with advanced ovarian cancer sensitive to platinum-based chemotherapy (AGOOVAR 2.14). Gynecol Oncol 130:31-37

Corte TJ, Keir GJ, Dimopoulos K et al (2014) Bosentan in pulmonary hypertension associated with fibrotic idiopathic interstitial pneumonia (BPHIT). Am J Respir Crit Care Med 190:208-217

Cozzi F, Pigatto E, Rizzo M et al (2013) Low occurrence of digital ulcers in scleroderma patients treated with bosentan for pulmonary arterial hypertension: a retrospective case-control study. Clin Rheumatol 32:679-683

Dai X, Galligan JJ, Watts SW et al (2004) Increased $\mathrm{O}_{2}^{--}$production and upregulation of ETB receptors by sympathetic neurons in DOCA-salt hypertensive rats. Hypertension 43:1048-1054

Dashwood MR, Tsui JC (2011) Further evidence for a role of endothelin-1 (ET-1) in critical limb ischaemia. J Cell Commun Signal 5:45-49

Denault AY, Pearl RG, Michler RE et al (2013) Tezosentan and right ventricular failure in patients with pulmonary hypertension undergoing cardiac surgery: the TACTICS trial. J Cardiothorac Vasc Anesth 27:1212-1217
Dilshara MG, Lee KT, Jayasooriya RG et al (2014) Downregulation of NO and PGE2 in LPS-stimulated BV2 microglial cells by trans-isoferulic acid via suppression of PI3 K/Akt-dependent $\mathrm{NF}-\kappa \mathrm{B}$ and activation of Nrf2-mediated HO-1. Int Immunopharmacol 18:203-211

Donate PB, Cunha TM, Verri WA Jr et al (2012) Bosentan, an endothelin receptor antagonist, ameliorates collagen-induced arthritis: the role of TNF- $\alpha$ in the induction of endothelin system genes. Inflamm Res 61:337-348

Dong F, Zhang X, Wold LE et al (2005) Endothelin-1 enhances oxidative stress, cell proliferation and reduces apoptosis in human umbilical vein endothelial cells: role of ETB receptor, NADPH oxidase and caveolin-1. $\mathrm{Br} \mathrm{J}$ Pharmacol 145: 323-333

Duan J, Xu H, Dai S et al (2008) Phytoestrogen alpha-zearalanol inhibits homocysteine-induced endothelin-1 expression and oxidative stress in human umbilical vein endothelial cells. Atherosclerosis 197:549-555

Dupuis J, Hoeper MM (2008) Endothelin receptor antagonists in pulmonary arterial hypertension. Eur Respir J 31:407-415

Ehrenreich H, Burd PR, Rottem M et al (1992) Endothelins belong to the assortment of mast cell-derived and mast cell-bound cytokines. New Biol 4:147-156

Elmarakby AA, Loomis ED, Pollock JS et al (2005) NADPH oxidase inhibition attenuates oxidative stress but not hypertension produced by chronic ET-1. Hypertension 45:283-287

Elshaboury SM, Anderson JR (2013) Ambrisentan for the treatment of pulmonary arterial hypertension: improving outcomes. Patient Prefer Adherence 7:401-409

Endo T, Uchida Y, Matsumoto $\mathrm{H}$ et al (1992) Regulation of endothelin-1 synthesis in cultured guinea pig airway epithelial cells by various cytokines. Biochem Biophys Res Commun 186:1594-1599

Erdem A, Meltem Sevgili A, Akbiyik F et al (2007) Tezosentan attenuates organ injury and mesenteric blood flow decrease in endotoxemia and cecal ligation and puncture. J Surg Res 141:211-219

Fang Y, Sang H, Yuan N et al (2013) Ethanolic extract of propolis inhibits atherosclerosis in ApoE-knockout mice. Lipids Health Dis 12:123

Fenhammar J, Andersson A, Frithiof R et al (2008) The endothelin receptor antagonist tezosentan improves renal microcirculation in a porcine model of endotoxemic shock. Acta Anaesthesiol Scand 52:1385-1393

Fenhammar J, Andersson A, Forestier J et al (2011) Endothelin receptor A antagonism attenuates renal medullary blood flow impairment in endotoxemic pigs. PLoS ONE 6:e21534

Ford RL, Mains IM, Hilton EJ et al (2008) Endothelin-A receptor inhibition after cardiopulmonary bypass: cytokines and receptor activation. Ann Thorac Surg 86:1576-1583

Forni M, Mazzola S, Ribeiro LA et al (2005) Expression of endothelin-1 system in a pig model of endotoxic shock. Regul Pept 131:89-96

Freund-Michel V, Guibert C, Dubois M et al (2013) Reactive oxygen species as therapeutic targets in pulmonary hypertension. Ther Adv Respir Dis 7:175-200

Gonon AT, Gourine AV, Middelveld RJ et al (2001) Limitation of infarct size and attenuation of myeloperoxidase activity by an endothelin A receptor antagonist following ischaemia and reperfusion. Basic Res Cardiol 96:454-462

Grassi G (2011) Selective endothelin receptor blockade in resistant hypertension: results of the DORADO trial. Expert Opin Pharmacother 12:153-155

Hansen PR (1995) Role of neutrophils in myocardial ischemia and reperfusion. Circulation 91:1872-1885 
Haque SU, Dashwood MR, Heetun M et al (2013) Efficacy of the specific endothelin A receptor antagonist zibotentan (ZD4054) in colorectal cancer: a preclinical study. Mol Cancer Ther 12:1556-1567

Haug C, Voisard R, Lenich A et al (1996) Increased endothelin release by cultured human smooth muscle cells from atherosclerotic coronary arteries. Cardiovasc Res 31:807-813

Hirata Y, Ishimaru S (2002) Effects of endothelin receptor antagonists on endothelin-1 and inducible nitric oxide synthase genes in a rat endotoxic shock model. Clin Sci 103(Suppl 48):332S-335S

Hukovic N, Hadziselimovic R (1998) Endothelin 1 action on isolated rat stomach and the role of calcium ions in ET 1 induced depolarization of smooth muscle cells $\mathrm{BC} 3 \mathrm{H} 1$. Biochem Mol Biol Int 46:877-886

Hynynen MM, Khalil RA (2006) The vascular endothelin system in hypertension-recent patents and discoveries. Recent Pat Cardiovasc Drug Discov 1:95-108

Imhof AK, Glück L, Gajda M et al (2011) Potent anti-inflammatory and antinociceptive activity of the endothelin receptor antagonist bosentan in monoarthritic mice. Arthritis Res Ther 13:R97

Iskit AB, Senel I, Sokmensuer C et al (2004) Endothelin receptor antagonist bosentan improves survival in a murine caecal ligation and puncture model of septic shock. Eur J Pharmacol 506:83-88

Jesmin S, Shimojo N, Yamaguchi N et al (2014) Effects of protease activated receptor (PAR)2 blocking peptide on endothelin-1 levels in kidney tissues in endotoxemic rat mode. Life Sci 102:127-133

Kaddoura S, Curzen NP, Evans TW et al (1996) Tissue expression of endothelin-1 mRNA in endotoxaemia. Biochem Biophys Res Commun 218:641-647

Kaszaki J, Wolfárd A, Boros M et al (1997) Effects of antiendothelin treatment on the early hemodynamic changes in hyperdynamic endotoxemia. Acta Chir Hung 36:152-153

Kawanabe Y, Nauli SM (2011) Endothelin. Cell Mol Life Sci 68:195-203

Keller S, Karaa A, Paxian M et al (2006) Inhibition of endothelin1-mediated up-regulation of iNOS by bosentan ameliorates endotoxin-induced liver injury in cirrhosis. Shock 25:306-313

Khalil RA (2011) Modulators of the vascular endothelin receptor in blood pressure regulation and hypertension. Curr Mol Pharmacol 4:176-186

Kim SJ, Kim JS, Kim SW et al (2011) Macitentan (ACT-064992), a tissue-targeting endothelin receptor antagonist, enhances therapeutic efficacy of paclitaxel by modulating survival pathways in orthotopic models of metastatic human ovarian cancer. Neoplasia 13:167-179

Kim SJ, Kim JS, Kim SW et al (2012) Antivascular therapy for multidrug-resistant ovarian tumors by macitentan, a dual endothelin receptor antagonist. Transl Oncol 5:39-47

Kitada K, Yui N, Matsumoto C et al (2009) Inhibition of endothelin ETB receptor system aggravates neointimal hyperplasia after balloon injury of rat carotid artery. J Pharmacol Exp Ther 331:998-1004

Kitada K, Ohkita M, Matsumura Y (2012) Pathological importance of the endothelin-1/ET(B) receptor system on vascular diseases. Cardiol Res Pract 2012:731970

Kleniewska P, Piechota-Polanczyk A, Michalski L et al (2013) Influence of block of NF-kappa B signaling pathway on oxidative stress in the liver homogenates. Oxid Med Cell Longev 2013:308358

Kohan DE, Pollock DM (2013) Endothelin antagonists for diabetic and non-diabetic chronic kidney disease. Br J Clin Pharmacol 76:573-579

Kohan DE, Pritchett Y, Molitch M et al (2011) Addition of atrasentan to renin-angiotensin system blockade reduces albuminuria in diabetic nephropathy. J Am Soc Nephrol 22:763-772
Konieczka K, Meyer P, Schoetzau A et al (2011) Effect of avosentan (SPP-301) in porcine ciliary arteries. Curr Eye Res $36: 118-124$

Krejci V, Hiltebrand LB, Erni D et al (2003) Endothelin receptor antagonist bosentan improves microcirculatory blood flow in splanchnic organs in septic shock. Crit Care Med 31:203-210

Kuklin V, Kirov M, Sovershaev M et al (2005) Tezosentan-induced attenuation of lung injury in endotoxemic sheep is associated with reduced activation of protein kinase C. Crit Care 9:R211R217

Leonard MG, Briyal S, Gulati A (2011) Endothelin B receptor agonist, IRL-1620, reduces neurological damage following permanent middle cerebral artery occlusion in rats. Brain Res 1420:48-58

Leonard MG, Briyal S, Gulati A (2012) Endothelin B receptor agonist, IRL-1620, provides long-term neuroprotection in cerebral ischemia in rats. Brain Res 1464:14-23

Li L, Chu Y, Fink GD et al (2003) Endothelin-1 stimulates arterial VCAM-1 expression via NADPH oxidase-derived superoxide in mineralocorticoid hypertension. Hypertension 42:997-1003

Li W, Sachidanandam K, Ergul A (2011) Comparison of selective versus dual endothelin receptor antagonism on cerebrovascular dysfunction in diabetes. Neurol Res 33:185-191

Li MW, Mian MO, Barhoumi T et al (2013) Endothelin-1 overexpression exacerbates atherosclerosis and induces aortic aneurysms in apolipoprotein E knockout mice. Arterioscler Thromb Vasc Biol 33:2306-2315

Lima VV, Giachini FR, Hardy DM et al (2011) O-GlcNAcylation: a novel pathway contributing to the effects of endothelin in the vasculature. Am J Physiol Regul Integr Comp Physiol 300:R236-R250

Lin CC, Hsieh HL, Shih RH et al (2013) Up-regulation of COX-2/ PGE2 by endothelin-1 via MAPK-dependent NF- $\kappa$ B pathway in mouse brain microvascular endothelial cells. Cell Commun Signal 11:8

Liu B, Zhou J, Chen H et al (1997) Expression and cellular location of endothelin-1 mRNA in rat liver following endotoxemia. Chin Med J 110:932-935

Loomis ED, Sullivan JC, Osmond DA et al (2005) Endothelin mediates superoxide production and vasoconstriction through activation of NADPH oxidase and uncoupled nitric-oxide synthase in the rat aorta. J Pharmacol Exp Ther 315:1058-1064

López-Sepúlveda R, Gómez-Guzmán M, Zarzuelo MJ et al (2011) Red wine polyphenols prevent endothelial dysfunction induced by endothelin-1 in rat aorta: role of NADPH oxidase. Clin Sci 120:321-333

Macdonald RL, Higashida RT, Keller E et al (2013) Randomised trial of clazosentan, an endothelin receptor antagonist, in patients with aneurysmal subarachnoid hemorrhage undergoing surgical clipping (CONSCIOUS-2). Acta Neurochir Suppl 115:27-31

Maemura K, Kurihara H, Morita $\mathrm{T}$ et al (1992) Production of endothelin-1 in vascular endothelial cells is regulated by factors associated with vascular injury. Gerontology 38(Suppl 1):29-35

Maron BA, Waxman AB, Opotowsky AR et al (2013) Effectiveness of spironolactone plus ambrisentan for treatment of pulmonary arterial hypertension (from the [ARIES] study 1 and 2 trials). Am J Cardiol 112:720-725

Mercier O, Sage E, Izziki M et al (2010) Endothelin A receptor blockade improves regression of flow-induced pulmonary vasculopathy in piglets. J Thorac Cardiovasc Surg 140:677-683

Mian MO, Idris-Khodja N, Li MW et al (2013) Preservation of endothelium-dependent relaxation in atherosclerotic mice with endothelium-restricted endothelin-1 overexpression. J Pharmacol Exp Ther 347:30-37

Miller K, Moul JW, Gleave M et al (2013) Phase III, randomized, placebo-controlled study of once-daily oral zibotentan (ZD4054) 
in patients with non-metastatic castration-resistant prostate cancer. Prostate Cancer Prostatic Dis 16:187-192

Montani D, Günther S, Dorfmüller P et al (2013) Pulmonary arterial hypertension. Orphanet J Rare Dis 8:97

Motte S, McEntee K, Naeije R (2006) Endothelin receptor antagonists. Pharmacol Ther 110:386-414

Naito Y, Yoshioka K, Tanaka K et al (2014) Endothelin B receptormediated encephalopathic events in mouse sepsis model. Life Sci. doi:10.1016/j.lfs.2014.03.012

Nelson JB, Fizazi K, Miller K et al (2012) Phase 3, randomized, placebo-controlled study of zibotentan (ZD4054) in patients with castration-resistant prostate cancer metastatic to bone. Cancer 118:5709-5718

Nitescu N, Grimberg E, Ricksten SE et al (2008) Endothelin B receptors preserve renal blood flow in a normotensive model of endotoxin-induced acute kidney dysfunction. Shock 29:402-409

Noshad H, Argani H, Nezami N et al (2009) Arterial atherosclerosis in patients with chronic kidney disease and its relationship with serum and tissue endothelin-1. Iran J Kidney Dis 3:203-209

Ohkita M, Tawa M, Kitada K et al (2012) Pathophysiological roles of endothelin receptors in cardiovascular diseases. J Pharmacol Sci 119:302-313

Oktar BK, Coşkun T, Bozkurt A et al (2000) Endothelin-1-induced PMN infiltration and mucosal dysfunction in the rat small intestine. Am J Physiol Gastrointest Liver Physiol 279:G483G491

Ozdemir R, Parlakpinar H, Polat A et al (2006) Selective endothelin A (ETA) receptor antagonist (BQ-123) reduces both myocardial infarct size and oxidant injury. Toxicology 219:142-149

Pan C, Wang J, Liu W et al (2012) Low tidal volume protects pulmonary vasomotor function from "second-hit" injury in acute lung injury rats. Respir Res 13:77

Patel T, McKeage K (2014) Macitentan: first global approval. Drugs 74:127-133

Persson BP, Halldorsdottir H, Lindbom L et al (2014) Heparinbinding protein (HBP/CAP37): a link to endothelin-1 in endotoxemia-induced pulmonary oedema? Acta Anaesthesiol Scand 58:549-559

Piechota A, Goraca A (2011) Influence of nuclear factor- $\kappa B$ inhibition on endothelin-1 induced lung edema and oxidative stress in rats. J Physiol Pharmacol 62:183-188

Piechota A, Polańczyk A, Goraca A (2011) Protective effects of endothelin-A receptor antagonist BQ123 against LPS-induced oxidative stress in lungs. Pharmacol Rep 63:494-500

Piechota-Polańczyk A, Gorąca A (2012) Influence of specific endothelin-1 receptor blockers on hemodynamic parameters and antioxidant status of plasma in LPS-induced endotoxemia. Pharmacol Rep 64:1434-1441

Piechota-Polanczyk A, Kleniewska P, Goraca A (2012) The influence of ETA and ETB receptor blockers on LPS-induced oxidative stress and NF- $\kappa B$ signaling pathway in heart. Gen Physiol Biophys 31:271-278

Quinn DI, Tangen CM, Hussain $M$ et al (2013) Docetaxel and atrasentan versus docetaxel and placebo for men with advanced castration-resistant prostate cancer (SWOG S0421): a randomised phase 3 trial. Lancet Oncol 14:893-900

Raghu G, Behr J, Brown KK et al (2013a) Treatment of idiopathic pulmonary fibrosis with ambrisentan: a parallel, randomized trial. Ann Intern Med 158:641-649

Raghu G, Million-Rousseau R, Morganti A et al (2013b) Macitentan for the treatment of idiopathic pulmonary fibrosis: the randomised controlled MUSIC trial. Eur Respir J 42:1622-1632

Reriani M, Raichlin E, Prasad A et al (2010) Long-term administration of endothelin receptor antagonist improves coronary endothelial function in patients with early atherosclerosis. Circulation 122:958-966
Rodriguez MR, Soria LR, Ventimiglia MS et al (2013) Endothelin-1 and -3 induce choleresis in the rat through ETB receptors coupled to nitric oxide and vagovagal reflexes. Clin Sci 125:521-532

Rodriguez-Pascual F, Redondo-Horcajo M, Lamas S (2003) Functional cooperation between Smad proteins and activator protein1 regulates transforming growth factor- $\beta$-mediated induction of endothelin- 1 expression. Circ Res 92:1288-1295

Ross EA (2012) Congestive renal failure: the pathophysiology and treatment of renal venous hypertension. J Card Fail 18:930-938

Roth J, De Souza GE (2001) Fever induction pathways: evidence from responses to systemic or local cytokine formation. Braz $\mathbf{J}$ Med Biol Res 34:301-314

Rullman E, Gustafsson T, Ahlborg G (2010) The impact of the endothelin type A receptor on regional endothelin-1 turnover, in particular renal endothelin-1 release, in humans. J Appl Physiol 108:1625-1630

Ryu SM, Kim HJ, Cho KR et al (2009) Myocardial protective effect of tezosentan, an endothelin receptor antagonist, for ischemiareperfusion injury in experimental heart failure models. J Korean Med Sci 24:782-788

Sagy M, Al-Qaqaa Y, Kim P (2013) Definitions and pathophysiology of sepsis. Curr Probl Pediatr Adolesc Health Care 43:260-263

Sánchez-Etayo G, Borrat X, Escobar B et al (2012) Effect of intraabdominal pressure on hepatic microcirculation: implications of the endothelin-1 receptor. J Dig Dis 13:478-485

Scalera F, Dittrich R, Beckmann MW et al (2002) Effect of endothelin-1 on intracellular glutathione and lipid peroxide availability and on the secretion of vasoactive substances by human umbilical vein endothelial cells. Eur J Clin Invest 32:556-562

Schelman WR, Liu G, Wilding G et al (2011) A phase I study of zibotentan (ZD4054) in patients with metastatic, castrate-resistant prostate cancer. Invest New Drugs 29:118-125

Schuuring MJ, Vis JC, van Dijk AP et al (2013) Impact of bosentan on exercise capacity in adults after the Fontan procedure: a randomized controlled trial. Eur J Heart Fail 15:690-698

Sengul O, Ferah I, Polat B et al (2013) Blockade of endothelin receptors with bosentan limits ischaemia/reperfusion-induced injury in rat ovaries. Eur $\mathrm{J}$ Obstet Gynecol Reprod Biol 170:458-463

Shao D, Park JE, Wort SJ (2011) The role of endothelin-1 in the pathogenesis of pulmonary arterial hypertension. Pharmacol Res 63:504-511

Shen J, Pan JW, Fan ZX et al (2013) Dissociation of vasospasmrelated morbidity and outcomes in patients with aneurysmal subarachnoid hemorrhage treated with clazosentan: a metaanalysis of randomized controlled trials. J Neurosurg 119:180-189

Sidharta PN, van Giersbergen PL, Dingemanse J (2013) Safety, tolerability, pharmacokinetics, and pharmacodynamics of macitentan, an endothelin receptor antagonist, in an ascending multiple-dose study in healthy subjects. J Clin Pharmacol 53:1131-1138

Simeone SM, Li MW, Paradis P et al (2011) Vascular gene expression in mice overexpressing human endothelin-1 targeted to the endothelium. Physiol Genomics 43:148-160

Singh G, Sharma B, Jaggi AS et al (2014) Efficacy of bosentan, a dual ETA and ETB endothelin receptor antagonist, in experimental diabetes induced vascular endothelial dysfunction and associated dementia in rats. Pharmacol Biochem Behav 124C:27-35

Sugiura M, Inagami T, Kon V (1989) Endotoxin stimulates endothelin-release in vivo and in vitro as determined by radioimmunoassay. Biochem Biophys Res Commun $161: 1220-1227$ 
Takatsuki S, Rosenzweig EB, Zuckerman W et al (2013) Clinical safety, pharmacokinetics, and efficacy of ambrisentan therapy in children with pulmonary arterial hypertension. Pediatr Pulmonol 48:27-34

Thakali K, Demel SL, Fink GD et al (2005) Endothelin-1-induced contraction in veins is independent of hydrogen peroxide. Am J Physiol Heart Circ Physiol 289:H1115-H1122

Thakkar SG, Choueiri TK, Garcia JA (2006) Endothelin receptor antagonists: rationale, clinical development, and role in prostate cancer therapeutics. Curr Oncol Rep 8:108-113

Tirapelli CR, Legros E, Brochu I et al (2008) Chronic ethanol intake modulates vascular levels of endothelin-1 receptor and enhances the pressor response to endothelin-1 in anaesthetized rats. Br J Pharmacol 154:971-981

Tonari M, Kurimoto T, Horie T et al (2012) Blocking endothelin-B receptors rescues retinal ganglion cells from optic nerve injury through suppression of neuroinflammation. Invest Ophthalmol Vis Sci 53:3490-3500

Vanêcková I, Kramer HJ, Bäcker A et al (2005) Early endothelin-A receptor blockade decreases blood pressure and ameliorates endorgan damage in homozygous Ren-2 rats. Hypertension 46:969-974

Virdis A, Schiffrin EL (2003) Vascular inflammation: a role in vascular disease in hypertension? Curr Opin Nephrol Hypertens $12: 181-187$

Viswanatha Swamy AH, Wangikar U, Koti BC et al (2011) Cardioprotective effect of ascorbic acid on doxorubicin-induced myocardial toxicity in rats. Indian J Pharmacol 43:507-511

Wanecek M, Weitzberg E, Rudehill A et al (2000) The endothelin system in septic and endotoxin shock. Eur J Pharmacol 407:1-15

Wang RF, Podos SM, Serle JB et al (2011) Effect of SPP 301, an endothelin antagonist, on intraocular pressure in glaucomatous monkey eyes. Curr Eye Res 36:41-46

Wedgwood S, Dettman RW, Black SM (2001) ET-1 stimulates pulmonary arterial smooth muscle cell proliferation via induction of reactive oxygen species. Am J Physiol Lung Cell Mol Physiol 281:L1058-L1067

Wong F, Moore K, Dingemanse J et al (2008) Lack of renal improvement with nonselective endothelin antagonism with tezosentan in type 2 hepatorenal syndrome. Hepatology 47:160-168

Wort SJ, Ito M, Chou PC et al (2009) Synergistic induction of endothelin-1 by tumor necrosis factor alpha and interferon $\gamma$ is due to enhanced NF- $\kappa \mathrm{B}$ binding and histone acetylation at specific $\kappa B$ sites. J Biol Chem 284:24297-24305

Xie K, Liu L, Yu Y et al (2014) Hydrogen gas presents a promising therapeutic strategy for sepsis. Biomed Res Int 2014:807635

Xu H, Lin L, Yuan WJ (2003) Antiarrhythmic effect of endothelin-A receptor antagonist on acute ischemic arrhythmia in isolated rat heart. Acta Pharmacol Sin 24:37-44

Yamashita J, Ogawa M, Nomura K et al (1993) Interleukin 6 stimulates the production of immunoreactive endothelin 1 in human breast cancer cells. Cancer Res 53:464-467

Yanagisawa M, Kurihara H, Kimura S et al (1988) A novel potent vasoconstrictor peptide produced by vascular endothelial cells. Nature 332:411-415

Yeager ME, Belchenko DD, Nguyen CM et al (2012) Endothelin-1, the unfolded protein response, and persistent inflammation: role of pulmonary artery smooth muscle cells. Am J Respir Cell Mol Biol 46:14-22

Yoon MH, Reriani M, Mario G et al (2013) Long-term endothelin receptor antagonism attenuates coronary plaque progression in patients with early atherosclerosis. Int J Cardiol 168:1316-1321

Yoshizumi M, Kurihara H, Sugiyama T et al (1989) Hemodynamic shear stress stimulates endothelin production by cultured endothelial cells. Biochem Biophys Res Commun 161:859-864

Zhang Y, Zhao C, He W et al (2014) Discovery and evaluation of asymmetrical monocarbonyl analogs of curcumin as antiinflammatory agents. Drug Des Devel Ther 8:373-382 